\title{
Changes in the Quality of Life of an Elderly Group of the Family Health Strategy
}

Thazia Costa ${ }^{1}$, Gilson de Vasconcelos Torres ${ }^{2}$, Rafaela Araújo Oliveira ${ }^{3}$, Marcelo Viana Costa ${ }^{4}$, Bruno Araújo da Silva Dantas ${ }^{5}$, Jessica Maria Arouca de Miranda ${ }^{6}$, Neidjany Patrícia Lima Torres ${ }^{6}$, Luana de Azevedo Souza ${ }^{7}$, Rosana Lúcia Alves de Vilar ${ }^{8}$

\section{Abstract}

Background: To analyze the quality of life of a group of elderly people enrolled in the Family Health Strategy of the Igapó neighborhood, in the city of Natal, Rio Grande do Norte, Brazil.

Methods: This is a longitudinal study with a quantitative approach. The process of data collection occurred in two different moments. The instruments used to collect data were: "Questionnaire on sociodemographic data" and the "Brazilian Version of the Short Form-36 Quality of Life Questionnaire (SF-36)."

Results: It was verified that most of them were women, with low purchasing power and low education level. There was a predominance of unmarried elderly individuals who did not perform work activities. Higher scores were identified for the emotional, physical and mental domains. In the first collection, lower scores regarding the general state of health and pain were observed. There were better percentages of improvement in the areas of General Health Status, Body Pain and Social Function and Physical Health dimension. The activities developed in the coexistence group together with the elderly were classified as educational, physical/functional and commemorative.

Conclusion: This study showed higher scores in the physical, functional and mental aspects, where the autonomy of the elderly is directly related, reflecting an active aging favoring a better quality of life.
1 Nurse, graduated from UFRN. Master's Degree in Public Health by Fiocruz, UFRN, Brazil.

2 Nurse, Post-Doctorate in Nursing in Évora/Portugal, Ph.D. in Nursing. Professor, UFRN, Scholarship at the Research Productivity PQ2/CNPq. UFRN, Brazil.

3 Student of nursing by UFRN. Scholarship holder of scientific initiation. UFRN, Brazil.

4 Nurse, PhD in Health Sciences at UFRN. Adjunct professor at UERN, Brazil.

5 Nurse graduated, UFRN. PhD student by the Graduate Program in Health Sciences. Master in nursing, Program in Nursing at the UFRN, Brazil.

6 Graduated from UFRN. Master's student by the Graduate Program in Health Sciences at the UFRN, Brazil.

7 Graduated from UnP. Master's student by the Graduate Program in Health Sciences at the UFRN, Brazil.

8 Nurse by UFRN. PhD in Social Sciences. Master in Social Sciences by UFRN, Brazil.

Contact information:

Rosana Lúcia Alves de Vilar.

Address: Nascimento de Castro, 1245. Ed. Cristo Redentor. Lagoa Nova, Natal, Brasil. 59056-450.

Tel: 558432349751.

Elderly; Quality of life; Health of the Elderly. 


\section{Introduction}

In the last decades in Brazil, there is a process of demographic transition, where it is heading for an accelerated population aging [1]. The elderly population in this scenario has already reached values greater than 20 million people in 2010, representing $10.8 \%$ of the total Brazilian population, and predominantly female [2].

Although the population aging phenomenon is present in a global context, the growth of the elderly in certain continents, countries or regions is manifested in different ways. This fact is associated with the different social, cultural and political characteristics of each territory [3].

Aging carries a range of physiological changes imposing the individual a gradual increase of physical and functional limitations, besides the high incidence of chronic diseases observed in the elderly [4]. This fact exposes these individuals to a greater risk of falls and dependence, being subject to several diseases and problems resulting from this process [5].

Faced with so many morbidities and diseases present in aging, the quality of life (QOL) has been gaining prominence in studies carried out in recent years, directly associated with the individual's health status [6]. The World Health Organization (WHO) puts into question the paradigm of active aging as a measure to circumvent and reduce morbidities and diseases, as a proposal for intervention in the public policies areas. This concept is defined by a process that aims to optimize opportunities for health, with the aim of improving QOL during aging [7].

In the perspective of active aging, maintaining the physical and mental state of the elderly is considered very important. Thus, cardiovascular diseases, neuromuscular atrophy, and improving cognitive function and, finally, the individual's QOL are prevented [8].

The maintenance of the quality of life, especially in relation to aging, is the responsibility of the Family Health Strategy (FHS), acting mainly in actions of promotion, prevention, follow-up of the elderly and follow-up of chronic diseases [9].

In this context, the Family Health Strategy (FHS) promotes interdisciplinary assistance through teams located in the context of Primary Care, aimed at identifying / intervening in individual and family demands [10], thus facilitating access to health, user satisfaction, and better quality of service [11]. Therefore, it is expected that its responsibilities will accompany the user with responsibility in the aging process, being able to identify and intervene in the possible fragilities that compromise health, considering how to be a member of the family and community [12].

This article shows a part of the results of a dissertation of the Post-Graduation Program in Family Health in the Northeast, from the Northeast Network of Family Health Training (RENASF), by the Federal University of Rio Grande do Norte (UFRN). The objective of this study was to analyze the QOL and the elderly enrolled in the Family Health Strategy (FHS) of the Igapó neighborhood, in the city of Natal, Rio Grande do Norte (RN), Brazil.

\section{Methods}

It is a longitudinal study, with a quantitative approach, performed at the FHS in the Igapó neighborhood, belonging to the municipality of Natal, in two moments, in November 2014 and November 2015.

The health services network in the Igapó neighborhood belongs to the North Sanitary District II, with a Basic Health Unit and a Family Health Unit (FHU). There is an elderly cohabitation group linked to the FHU, in which activities to promoted to the elderly's health are developed.

The population of the study was the elderly registered in the FHS of Igapó in Natal. The sample consisted of 11 elderly people who, besides being enrolled in the FHS, participated in the elderly cohabitation group. For this study was considered 
elderly, people aged 60 or over, according to the Brazilian Institute of Geography and Statistics [13].

The elderlies are part of the cohabitation group, nominated Francisco André, one of the first members of the group and at the time he was who assumed the position of president of the Commercial Association of the neighborhood. The group consists of twenty-eight elderly people, twenty-two women, and only six men. This fact evidences a greater presence of women in the services developed by FHU. The age group of the elderly was from 60 to 85 years old.

The inclusion criteria in the study were: to be enrolled in Francisco André group; to live within the area covered by the FHU; to be a member of the elderly group for at least four years, attending the scheduled activities. The exclusion criteria included: The elderly with cognitive deficit who were not able to answer the applied questionnaire.

The data collection process occurred in two moments to analyze the results found in each of them. The first collection occurred in November 2014, with the subsequent collection in November of the following year (2015).

Data were collected through the application of two questionnaires: the "Socio-demographic Data Questionnaire," aimed at surveying the sociodemographic profile of the study participants, highlighting the following variables: gender, age group, marital status, education income and current work situation.

The "Brazilian version of the Short Form-36 Quality of Life Questionnaire (SF-36)" [14], aimed at measuring life quality through numerical scales associated with the described response, improved or worsened of eight QOL domains using a time of the previous four weeks. It can be considered a generic instrument of easy application and understanding. It is divided into two parts: the first part to assess the state of health, and the second part to assess the impact of the disease on daily life. The instrument contains 36 items, divided into 8 scales or domains, which are: functional aspect, physical aspect, pain, general health, vitality, the social aspect, emotional aspect and mental health and two dimensions of physical and mental health. It presents a final score of 0 (zero) to 100 (obtained by calculation of Rawscale), where zero corresponds to the worst general health condition, and 100 corresponds to the best health status [15].

In addition, was used the Fransisco André data collection/control book, which is the responsibility of the team (Nurse and Community Health Agent) of the FHS Igapó to identify the typologies of activities developed during the year of 2016, in this sense, was classified as educational; Physical/functional and commemorative.

The programs Microsoft Excel 2013 and the Statistical Package for the Social Sciences (SPSS) 20.0 were used for the tabulation and data analysis. For the tabulation of sociodemographic data, the table was organized, presenting frequency and percentage referring to total $n$ (sample). It was similarly for each variable. When analyzing the $\mathrm{QOL}$, the maximum, minimum values, besides the averages and their Standard Deviations (SD) were observed for the two collections. Because they were two related samples and scalar variables, the Wilcoxon Test was used to verify the significance of the data differences. For that, a $p$-value $\leq 0.005$ was established as a criterion for statistical significance.

Regarding the ethical aspects, all the participants were duly clarified before the applications of the questionnaires, regarding the objectives of the research and other details. The Free and Informed Consent Term (TCLE) was presented to agree to participate in the research, and it was signed by the researcher and the participant in two copies, assigned to each of the parties.

This research had previous approval by the Research Ethics Committee of the University Hospital Onofre Lopes (Natal/Brazil), under the Certificate of Ethical Appreciation of (CAAE) $n^{\circ}$ 21996313.7.0000.5537, in accordance with the regulations of Resolution 
196/96 and the current Resolution 466/2012 of the National Health Council, regarding the ethical aspects observed regarding the conduct of research involving human beings.

\section{Results}

Most of the eleven elderly participants of this study were women with low purchasing power according to Table 1. Moreover, there was a predominance of elderly people without a partner, with low educational level and without performing paid work activities.

Table 1. Sociodemographic characteristics of elderly people enrolled in Primary Health Care.

\begin{tabular}{|l|c|c|}
\hline Sociodemographic Characteristics & $\mathbf{n}$ & $\%$ \\
\hline Female & 10 & 91.0 \\
\hline Male & 1 & 9.0 \\
\hline Age group & & \\
\hline 64-71 & 8 & 72.7 \\
\hline 72-80 & 3 & 27.3 \\
\hline Marital Status & & \\
\hline Single/Widow/Separated & 7 & 63.6 \\
\hline Married/Stable Union & 4 & 36.4 \\
\hline Income & & \\
\hline 1 to 3 MW & 11 & 100.0 \\
\hline Education level & & \\
\hline 0 to 5 years & 10 & 90.9 \\
\hline 6 to 11 years & 1 & 9.1 \\
\hline Current Job Situation & 8 & 72.7 \\
\hline Not paid employment & 3 & 27.3 \\
\hline Paid employment & & \\
\hline
\end{tabular}

Regarding the typologies of activities developed in the coexistence group Francisco André (Table 2), there are identified: Educational, Physical/Functional, and Commemorative. In this sense, oral health actions pertinent to the Educational and physical activity related to Physical/Functional were highlighted when compared to the other subtypes.
Table 2. Types of activities developed in the coexistence group Francisco André.

\begin{tabular}{|l|c|c|}
\multicolumn{1}{|c|}{ Types Of Activities } & $\mathbf{n}$ & $\%$ \\
\hline Educational & & \\
\hline Oral Health & 3 & 25.0 \\
\hline Renal Function & 1 & 8.3 \\
\hline Pink October & 1 & 8.3 \\
\hline Art Office & 1 & 8.3 \\
\hline Physical/Functional & & \\
\hline Physical activity & 2 & 16.7 \\
\hline Commemorative & & \\
\hline Mother's day & 1 & 8.3 \\
\hline June parties & 1 & 8.3 \\
\hline Elderly's day & 1 & 8.3 \\
Christmas & 1 & 8.3 \\
\hline Total & 12 & 100.0 \\
\hline
\end{tabular}

Regarding the evaluation of the QOL of the elderly participants, there was a predominance of the means referring to the physical, emotional and functional aspects of the first collection, as well as better QOL related to the mental health dimension. On the other hand, there was a worse QOL related to the general health domain, followed by pain.

Regarding the second collection, there were higher scores referring to emotional, physical and mental health and mental health dimensions. As with the first moment, there was worse QOL regarding the general state of health and pain. Regarding the specified measurements, no significant statistical difference was observed. Also, the reported health domain, unlike the other domains and dimensions, presents a variation from 0 to 5 . In this sense, similar scores were identified in the first and second moments.

Finally, all the domains and dimensions of the QOL obtained higher scores in the second collection. This can be associated with the participation in the group of the elderly in the activities performed.

(Table 3) 
Table 3. Quality of life of the elderly members of the cohabitation group Francisco André of the ESF in the neighborhood of Igapó.

\begin{tabular}{|c|c|c|c|c|c|}
\hline \multirow[b]{2}{*}{ SF-36 } & \multicolumn{2}{|c|}{$1^{\circ}$ Collection } & \multicolumn{2}{|c|}{$2^{\circ}$ collection } & \multirow{2}{*}{\begin{tabular}{|c|} 
p-value \\
Wilcoxon \\
Test \\
\end{tabular}} \\
\hline & $\min -\max$ & $\begin{array}{c}\text { average } \\
\text { (SD) }\end{array}$ & $\min -\max$ & $\begin{array}{c}\text { Average } \\
\text { (SD) }\end{array}$ & \\
\hline \multicolumn{6}{|l|}{ Domains } \\
\hline $\begin{array}{l}\text { Emotional } \\
\text { Aspects }\end{array}$ & $0-100$ & $\begin{array}{c}60.6 \\
(38.9)\end{array}$ & $0-100$ & $\begin{array}{c}81.8 \\
(40.4)\end{array}$ & 0.227 \\
\hline $\begin{array}{l}\text { Physical } \\
\text { Aspects }\end{array}$ & $0-100$ & $\begin{array}{c}61.3 \\
(35.9)\end{array}$ & $0-100$ & $\begin{array}{c}72.7 \\
(34.3)\end{array}$ & 0.368 \\
\hline $\begin{array}{l}\text { Mental } \\
\text { Health }\end{array}$ & $32-80$ & $\begin{array}{c}57.4 \\
(13.5)\end{array}$ & $32-96$ & $\begin{array}{c}70.9 \\
(20.7)\end{array}$ & 0.066 \\
\hline $\begin{array}{l}\text { Social } \\
\text { Function }\end{array}$ & $25-75$ & $\begin{array}{c}51.1 \\
(11.8)\end{array}$ & $25-100$ & $\begin{array}{c}69.4 \\
(28.6)\end{array}$ & 0.107 \\
\hline $\begin{array}{l}\text { Functional } \\
\text { Aspect }\end{array}$ & $10-100$ & $\begin{array}{l}59.0 \\
(26.6)\end{array}$ & $35-100$ & $\begin{array}{c}67.7 \\
(26.5)\end{array}$ & 0.150 \\
\hline Vitality & $40-85$ & $\begin{array}{c}51.8 \\
(13.8)\end{array}$ & $30-100$ & $\begin{array}{l}61.8 \\
(17.9)\end{array}$ & 0.184 \\
\hline Body Pain & $0-60$ & $\begin{array}{l}36.3 \\
(18.5)\end{array}$ & $10-100$ & $\begin{array}{l}49.6 \\
(24.7)\end{array}$ & 0.282 \\
\hline $\begin{array}{l}\text { Genderal } \\
\text { Health } \\
\text { State }\end{array}$ & $15-50$ & $32.7(9.5)$ & $25-77$ & $\begin{array}{l}49.5 \\
(16.1)\end{array}$ & 0.007 \\
\hline \multicolumn{6}{|l|}{ Dimensions } \\
\hline $\begin{array}{l}\text { Mental } \\
\text { Health }\end{array}$ & $32-80$ & $\begin{array}{c}57,4 \\
(13,5)\end{array}$ & $35-95$ & $\begin{array}{c}66.8 \\
(18.4)\end{array}$ & 0.021 \\
\hline $\begin{array}{l}\text { Physical } \\
\text { Health }\end{array}$ & $34-61$ & $47,3(8,5)$ & $43-85$ & $\begin{array}{c}60.3 \\
(13.4)\end{array}$ & 0.010 \\
\hline $\begin{array}{l}\text { Escore } \\
\text { Total }\end{array}$ & $40-63$ & $50,8(7,9)$ & $37-90$ & $\begin{array}{l}65.4 \\
(16.0)\end{array}$ & 0.010 \\
\hline
\end{tabular}

Table 4. Percentage of improvement of the Quality of Life of the elderly members of the cohabitation group Francisco André of the ESF in the neighborhood of Igapó.

\begin{tabular}{|l|c|}
\multicolumn{1}{|c|}{ SF-36 } & $\begin{array}{c}\text { Percentage of improved } \\
\text { QOL }\end{array}$ \\
\hline Domains & \\
\hline General health status & 51 \\
\hline Body ache & 37 \\
\hline Social role & 36 \\
\hline Emotional Aspects & 35 \\
\hline Mental health & 24 \\
\hline
\end{tabular}

\begin{tabular}{|l|c|}
\hline \multicolumn{1}{|c|}{ SF-36 } & $\begin{array}{c}\text { Percentage of improved } \\
\text { QOL }\end{array}$ \\
\hline Domains & 19 \\
\hline Physical aspect & 19 \\
Vitality & 15 \\
\hline Functional aspect & \\
\hline Dimensions & 27 \\
\hline Physical Health & 16 \\
\hline Mental Health & 29 \\
\hline Total Score & \\
\hline
\end{tabular}

When evaluating the percentage of QOL improvement in the elderly (Table 4), the prevalence of the General Health, Body Pain, and Social Function domains and the Physical Health dimension were predominant.

\section{Discussion}

It can be observed that the result presented in this research highlights the highest percentage of elderly women, which may be related to greater longevity in relation to men [16], since there is a greater search for health services [17], As well as identified in other studies [18-19]. However, a recent study aimed at assessing quality of life in older people in Iran pointed to a statistically significant difference when comparing the sex condition, revealing a high level of quality of life among male participants [20].

The predominant age group was between 64 and 71 years old. It is worth mentioning that every 10 years lived, the functional reduction is accentuated. Over 80 years old, studies have shown that there are 25 times greater chances of functional capacity decline, related to the elderly with fewer years of life. Other studies reported that compared to young people, people over 80 years old have very limited health $[16,17,21,22]$.

This research identified the predominance of elderly in the single, widowed or separated marital status, different from the marital situation of other 
surveys in which they showed that the majority were married. [21-23].

Most of those surveyed presented less than five years of education, similar to previous studies carried out with elderly people in the rural area of Minas Gerais [21]. Some studies showed that a higher level of literacy is a social indicator that brings greater chances of professional success to the individual, allowing the elderly a possible life with healthy habits [22-25]. Thus, the low level of education of the elderly presented in this research imposes the need to program educational actions to appropriate to the demanded profile. In addition, there were significant correlations between QOL results assessed by the SF-36 with socioeconomic variables, indicating better QOL among the literate elderly $(P=0.001)$ [26], demonstrating the importance of considering this factor in an attempt to promote QOL Individuals.

A study carried out in Uberaba-MG states that for an active and healthy aging, it is fundamental the elderly to practice activities and be inserted into society [25]. It was observed in this study that, although they do not develop work activities, most the elderlies develop other types of activities in their daily life. On the other hand, evidence suggests significant associations between the Mental Health dimension of $\mathrm{QOL}$ and the employment status $(P=0.005)$ [27], becoming a matter of concern, since it reveals its influence in $\mathrm{QOL}$, and may be related to the lower percentage of QOL attributed to the mental health dimension in this study.

It is observed that the QOL is directly related to the independence and autonomy of the elderly [28], characteristics that are related mainly to the physical, functional and mental aspects, in which this study showed better scores. Recent research developed in the United States showed improvement of QOL among the elderly with better emotional well-being $(P<.001)$, general higher physical function and fewer depressive symptoms (GDS-SF)
$(P<.001)$, also, greater emotional or informational social support $(P=0.004)[29]$, reaffirming the findings of this research.

Given this relationship, actions that aim to promote the physical and emotional well-being of this group are necessary, through an incentive to perform activities of daily living, as well as changes in lifestyle and participation in social groups [30]. It is verified that the elderly that participate in social groups had an active aging and monitored, tending to have a better QOL. However, the low-income population has greater difficulty in insertion in social participation [31].

The subjects of this research actively participate in a group of elderly people linked to ESF, which may be indicative of an improvement in the score when comparing the first and second collections, especiaIly the General Health State, Pain in the Body and Social Function, which obtained a better percentage of QOL improvement.

In this sense, when participating in a social group, it is understood that the elderly has better access to knowledge that will certainly impact on their high care, through orientations, targeted lectures and sharing of cultural experiences and social interaction among the participants. This research pointed out a greater number of educational / physical activities related to oral, renal, female (October pink) health and physical activity, which could result in positive changes in QOL.

This study, which included 349 elderly people in a self-training program in Masjed Sulaiman, aimed at generating behavioral changes related speciaIly to balanced diet, physical activity and self-care through lectures and demonstrations, observed improvement in all dimensions of QOL with statistical significance after training $(p<0.001)$ as measured by SF-36 [32].

A study carried out with the elderly [30] found that unmarried or widowed elderly people with low education level had worse QOL than the others. These data may have influenced the overall score 
of this survey not to be higher, although they tend to have a good QOL.

One of the domains with the lowest score was the pain, which may be related to factors related to health decline. Therefore, the prevention and treatment of pain are essential [31].

A recent study developed in Santa Maria/RS showed better QOL scores related to the elderly who perform physical activity regularly when compared to those who are insufficiently active. They had better scores of all SF-36 domains (Functional capacity, pain, vitality, mental health, limitation by physical aspects, general health, social aspects and limitation by emotional aspects) [33] having a relationship with the improvement of QOL identified in this study, considering that physical activity was highlighted among the types developed in the coexistence group.

Based on the above, it is noted the importance of ESFs in the elderly QOL since this service monitors, promotes, prevents, treats and rehabilitates, and it is also responsible for the continuity of care through reference and counter-referral. The ESF team plays a fundamental role in this service, since it establishes a relationship of trust with the elderly, and contributing to the development of strategies that aim to improve QOL [30].

\section{Conclusion}

This study showed that all the scores were improved, being significant the General Health Status and Physical and Mental Health Dimensions. Also, there were better percentages of improvements related to the General Health, Body Pain, Social Function and Physical Dimension, thus reflecting in an active aging and providing a better quality of life.

It can be noticed that the surveyed elderly had better QOL scores because they were members of a cohabitation group, which performed activities classified as educational, physical and commemorative; enabling moments of entertainment, interaction and physical stimulation among the elderly.

It was also identified that the group has characteristics of homogeneity, considering that some specific conditions affect the quality of life and influence the aging process. The understanding of this stage of life is important not only for the changes that have occurred but also for knowing and developing strategies that minimize the effects of aging to guarantee the experience of this life cycle in an autonomous and qualitatively positive way.

This study was of great relevance to subsidize knowledge and support ESF, considering that this service aims at promotion, prevention, treatment, and rehabilitation, being also responsible for the continuity of care and successively the progression of the quality of life of these elderly, aiming at their social inclusion, and reformulating the stigma of old age.

It is expected that the results obtained with the research enable to broaden the knowledge in the area, offering subsidies for the organization of an integrated work, aiming to improve the health conditions and quality of life of this population.

\section{References}

1. Küchemann BA. Envelhecimento populacional, cuidado e cidadania: velhos dilemas e novos desafios. Soc Estado [Internet]. 2012 Jan [cited 2016 Jun 15];27(1):[about 16 p.]. Available from: 165-180. http://www.scielo.br/scielo.php?script=sci arttext\&pi $\underline{d}=$ S0102-69922012000100010

2. Instituto Brasileiro de Geografia e Estatística [Internet]. Rio de Janeiro: Sinopse do Senso Demográfico de 2010; c2011 [updated 2016 Jul 15; cited 2016 Jun 15]. Available from: http:// www.ibge.gov.br/home/estatistica/populacao/censo2010/ default sinopse.sht

3. Baldoni AO, Pereira LRL. O impacto do envelhecimento populacional para o sistema de saúde sob a ótica da farmacoepidemiologia: uma revisão narrativa. Rev Ciênc Farm Básica Apl [Internet]. 2011 [cited 2016 Jul 15];32(3):[about 8 p.]. Available from: http://serv-bib.fcfar.unesp.br/seer/index.php/ Cien Farm/article/viewFile/1505/1173 
4. Serbim AK, Gonçalvez AVF, Paskulin LMG. Caracterização sociodemográfica, de saúde e apoio social de idosos usuários de um serviço de emergência. Rev Gaúcha Enferm [Internet]. 2013 Mar [cited 2016 Jul 15];34(1):[about 8 p.]. Available from: $\quad$ http://www.scielo.br/scielo.php?script=sci arttext\&pid $=$ S1983-14472013000100007

5. Del Duca GF, Martinez AD, Bastos GAN. Perfil do idoso dependente de cuidado domiciliar em comunidades de baixo nível socioeconômico, de Porto Alegre, Rio Grande do Sul. Rev Ciênc Saúde Coletiva [Internet] 2012 May [cited 2016 Jul 15]; 17(5): [about 7 p.]. Available from: http://www.scielo.br/scielo. php? script=sci arttext\&pid=\$1413-81232012000500010 11591165.

6. Vieira KFL, Reis ID, Segundo JBM, Fernandes ME, Macdonald TTV. Representações sociais da qualidade de vida na velhice. Psicol cienc prof [Internet]. 2012 [cited 2016 Jul 25]; 32(3): [about 11 p.]. Available from: http://www.scielo.br/scielo. php?script=sci arttext\&pid=\$1414-98932012000300002 540$\underline{51}$

7. Bárrios MJ, Fernandes AA. A promoção do envelhecimento ativo a nível local: análise de programas de intervenção autárquica. Rev Port Saude Pub [Internet]. 2014 Nov [cited 2016 Jun 25]; 32(2): [cited 8 p.]. Available from: https://www.researchgate.net/ publication/268690417 A promocao do envelhecimento ativo ao nivel local analise de programas de intervencao autarquica

8. Tavares BB, Moraes H, Deslandes AC, Laks J. Impact of physical exercise on quality of life of older adults with depression or Alzheimer's disease: a systematic review. Trends Psychiatry Psychother [Internet]. 2014 Jul [cited 2016 Jun 28]; 36(3): [about 6 p.]. Available from: http://www.scielo.br/scielo.php?script=sci_ arttext\&pid=\$2237-60892014000300134

9. Motta LB, Aguiar AC, Caldas CP. The Family Health Strategy and healthcare for the elderly: experiences in three Brazilian cities. Cad Saúde Pública [Internet]. 2011 Apr [cited 2016 Dec 01]; 27(4): [about 8 p.]. Available from: http://www.scielosp.org/ scielo.php?script=sci_arttext\&pid=S0102-311X2011000400017 \&lng=en\&nrm=iso\&tlng=em

10. Macinko J, Harris MJ. Brazil's Family Health Strategy - Delivering Community-Based Primary Care in a Universal Health System. N Engl J Med [Internet]. 2015 June [cited 2016 Dec 1]; 372: [about 5 p.]. Available from: http://www.nejm.org/doi/pdf/10.1056/ NEJMp1501140

11. Macinko J, Costa MFL. Access to, use of and satisfaction with health services among adults enrolled in Brazil's Family Health Strategy: evidence from the 2008 National Household Survey. Trop Med Int Health [Internet]. 2012 [cited 2016 Dec 1]; 17 (1): [about 7 p.]. Available from: https://www.ncbi.nlm.nih.gov/ pubmed/21859440
12. Clares JWB, Freitas MC, Almeida PC, Galiza FT, Queiroz TA. Perfil de idosos cadastrados numa unidade básica de saúde da família de Fortaleza-CE. Rev Rene [Internet]. 2011 [cited 2015 June 28]; 12(esp): [about 7 p.]. Available from: http://www. revistarene.ufc.br/revista/index. php/revista/article/view/325

13. Brasil. Lei n. 10.741, de 10 de outubro de 2003. Dispõe sobre o Estatuto do Idoso e dá outras providências. Diário Oficial da União, Brasília, 3 out. 2003. Seção 1:1-6.

14. Ciconelli RM, Ferraz MB, Santos W, Meinão I, Quaresma MR. Tradução para língua portuguesa e validação do questionário genérico de avaliação de qualidade de vida SF-36 (Brasil SF-36). Rev Bras Reumatol [Internet]. 1999 [cited 2016 Dec 1]; 39(3): [about 8 p.]. Available from: http://www.ufjf.br/ renato nunes/files/2014/03/Valida\%C3\%A7\%C3\%A3o-doQuestion\%C3\%A1rio-de-qualidade-de-Vida-SF-36.pdf

15. Faria HTG, Veras VS, Xavier ATF, Teixeira CRS, Zanetti ML, Santos MA. Quality of life in patients with diabetes mellitus before and after their participation in an educational program. Rev Esc Enferm USP [Internet] 2013 [cited 2016 Dec 1]; 47(2): [about 7 p.] Available from: www.ee.usp.br/reeusp/

16. Pilger C, Menon MH, Mathias TAF. Características sociodemográficas e de saúde de idosos: contribuições para os serviços de saúde. Rev Latinoam Enferm [Internet]. 2011 Sept [cited 2016 Sept 25]; 19(5): [about 9 p.]. Available from: http://www.scielo.br/scielo.php?pid=S0104$11692011000500022 \&$ script=sci arttext\&tlng $=\mathrm{pt}$

17. Mazo GZ, Krug RR, Virtuoso JF, Lopes MA, Tavares AG. Nível de Atividade Física de Idosos Longevos Participantes de Grupos de Convivência. BEPA Bol Epidemiol Paul [Internet]. 2012 Oct [cited 2016 Sept 25]; 9(106): [about 11 p.]. Available from: $\quad$ http://periodicos.ses.sp.bvs.br/scielo.php?script=sci_ arttext\&pid=S1806-42722012001000001\&lng=pt

18. Carvalho VCHS, Rossato SL, Fuchs FD, Harzheim E, Fuchs SC. Sociodemographic and clinical characterization of elderly assisted in primary health care. J Nursing UFPE on line [Internet]. 2015 [cited 2016 Dec 1]; 9(10): [about 8 p.]. Available http:// www.revista.ufpe.br/revistaenfermagem/index.hph/revista/ article/view/8203/pdf_8699

19. Carvalho HS, Rossato SL, Fuchs FD, Harzheim E, Fuchs SC. Assessment of primary health care received by the elderly and health related quality of life: a cross-sectional study. BMC Public Health [Internet]. 2013 Jun [cited 2016 Dec 1]; 24(13): [about 9 p.]. Available from: https://www.ncbi.nlm.nih.gov/ pubmed/23800179

20. Khaje-Bishak Y, Payahoo L, Pourghasem B, Asghari Jafarabadi $M$. Assessing the quality of life in elderly people and related factors in tabriz, iran. J Caring Sci [Internet] 2014 Dec [cited 2016 Dec 1]; 3(4): [about 8 p.]. Available from: https://www. ncbi.nlm.nih.gov/pubmed/25717455 
21. Tavares DMS, Paiva MM, Dias FA, Diniz MA, Martins NPF. Características sociodemográficas e qualidade de vida de idosos com hipertensão arterial sistêmica que residem na zona rural: importância do papel do enfermeiro. Rev Latinoam Enferm [Internet] 2013 Mar [cited 2016 Sept 25]; 21(2): [about 8 p.]. Available from: http://www.scielo.br/pdf/rlae/v21n2/pt 01041169-rlae-21-02-0515.pdf

22. Serbim AK, Gonçalves AVF, Paskulin LMG. Caracterização sociodemográfica, de saúde e apoio social de idosos usuários de um serviço de emergência. Rev Gaúch Enferm [Internet] 2013 Mar [cited 2016 Sept 25]; 4(1): [about 8 p.]. Available from: $\quad$ http://www.scielo.br/scielo.php?script=sci arttext\&pid $=$ S1983-14472013000100007

23. Vieira CPB, Sá MS, Madeira MZA, Luz MHBA. Caracterização e fatores de risco para úlceras por pressão na pessoa idosa hospitalizada. Rev RENE [Internet] 2014 Jul [cited 2016 Sept 28]; 15(4): [about 8 p.]. Available from: www.revistarene.ufc.br/ revista/index.php/revista/article/download/1777/pdf

24. Rocha SV, Almeida MMG, Araújo TM, Rodrigues WKM, Santos LB, Virtuoso Júnior JS. Prevalência de transtornos mentais comuns entre idosos residentes em município do nordeste do brasil. Rev Salud Pública [Internet] 2012 Aug [cited 2016 Sept 30]; 14(4): [about 9 p.]. Available from: http://www.scielosp. org/pdf/rsap/v14n4/v14n4a07.pdf

25. Ferreira PCS, Tavares DMS, Rodrigues RAP. Características sociodemográficas, capacidade funcional e morbidades entre idosos com e sem declínio cognitivo. Acta Paul Enferm [Internet]. 2011 Oct [cited 2016 Sept 28]; 24(1): [about 7 p.]. Available from: http://www.scielo.br/pdf/ape/v24n1/v24n1a04.pdf

26. Heydari J, Rouhani S, Mohammadpour RA. Aging populations' quality of life: An emerging priority for public health system in Iran. Life Sci J [Internet]. 2012 [cited 2016 Dec 1]; 9(4): [about 6 p.]. Available from: http://www.lifesciencesite.com

27. Farzianpour F, Foroushani AR, Badakhshan A, Gholipour M, Roknabadi EH. Quality of Life for Elderly Residents in Nursing Homes. Glob J Saúde Sci [Internet]. 2016 Apr [cited 2016 Dec 1]; 8(4): 9 p.]. Available from: http://www.ccsenet.org/journal/ index.php/gjhs/article/view/51676

28. Leite MT, Winck MT, Hildebrandt LM, Kirchner RM, Silva LAAA. Qualidade de vida e nível cognitivo de pessoas idosas participantes de grupos de convivência. Rev Bras Geriatr Gerontol [Internet]. 2012 July [cited 2016 Sept 28]; 15(3): [cited 11 p.]. Available from: http://www.scielo.br/scielo.php?script=sci artte xt\&pid=S1809-98232012000300009

29. Naylor MD, Hirschman KB, Hanlon AL, Abbott KM, Bowles KH, Foust J, Shah S, Zubritsky C. Factors Associated With Changes in Perceived Quality of Life Among Elderly Recipients of Long-Term Services and Supports. J Am Med Dir Assoc [Internet]. 2016 Jan [cited 2016 Dec 1]; 17(1): [about 9 p.]. Available from: 10.1016/j. jamda.2015.07.019
30. Lobo AJS, Santos L, Gomes S. Nível de dependência e qualidade de vida da população idosa. Rev Bras Enferm [Internet]. 2014 Nov [cited 2016 Sept 26]; 67(6): [about 7 p.]. Available from: http://www.scielo.br/pdf/reben/v67n6/0034-7167reben-67-06-0913.pdf

31. Lenardt $\mathrm{MH}$, Lenardt $\mathrm{MH}$, Carneiro NHK, Albino J, Willig MH. Qualidade de vida de idoso fragilizado da atenção primária. Acta Paul Enferm [Internet]. 2014 [cited 2016 Sept 28]; 27(5): [about 5 p.]. Available from: http://www.scielo.br/pdf/ape/ v27n5/pt 1982-0194-ape-027-005-0399.pdf

32. Farzianpour F, Hosseini Sh, Rostami M, Pordanjani Sh B, Hosseini SM. Quality of Life of the Elderly Residents. Am J Applied Sci [Internet]. 2012 [cited 2016 Dec 1]; 9 (1): [about 4 p.]. Available from: http://thescipub.com/PDF/ajassp.2012.71.74.pdf

33. Cordeiro J, Castillo BLD, Freitas CS, Marisa MP. Efeitos da atividade física na memória declarativa, capacidade funcional e qualidade de vida em idosos. Rev Bras Geriatr Gerontol [Internet]. 2014 Jul [cited 2016 Sept 28]; 17(3): [about 12 p.]. Available from: http://www.scielo.br/pdf/rbgg/v17n3/18099823-rbgg-17-03-00541.pdf

\section{Publish in International Archives of Medicine}

International Archives of Medicine is an open access journal publishing articles encompassing all aspects of medical science and clinical practice. IAM is considered a megajournal with independent sections on all areas of medicine. IAM is a really international journal with authors and board members from all around the world. The journal is widely indexed and classified Q2 in category Medicine. 